\title{
Impact of Monetary Policy on Economic Growth in Nigeria
}

\author{
Ajibola Ayodeji, Adeyemi Oluwole \\ Department of Economics, Chrisland University, Abeokuta, Nigeria \\ Email: dejiajibola294@yahoo.com,wolejadeyemi@gmail.com
}

How to cite this paper: Ayodeji, A. and Oluwole, A. (2018) Impact of Monetary Policy on Economic Growth in Nigeria. Open Access Library Journal, 5: e4320. https://doi.org/10.4236/oalib.1104320

Received: January 10, 2018

Accepted: February 10, 2018

Published: February 13, 2018

Copyright ( 2018 by authors and Open Access Library Inc.

This work is licensed under the Creative Commons Attribution International License (CC BY 4.0).

http://creativecommons.org/licenses/by/4.0/

\section{(c) (i) Open Access}

\begin{abstract}
The paper examined the impact of monetary policy on economic growth in Nigeria by developing a model that is able to investigate how monetary policy of the government has affected economic growth through the use of multi-variable regression analysis. We proxied the variables of monetary policy instruments to include: Money Supply (MS), Exchange Rate (ER), Interest Rate (IR), and Liquidity Ratio (LR). Economic growth was represented by Gross Domestic Product (income) at constant prices. Unit root test was conducted and all our estimating variables were stationary at first difference except the component of interest rate which shows that our model interpretation would not be spurious and a true representation of the relationships that exists between the explained and explanatory variables. Error Correction Model was introduced in our estimation in order to have a parsimonious model. From our result, two variables (money supply and exchange rate) had a positive but fairly insignificant impact on economic growth. Measures of interest rate and liquidity ratio on the other hand, had a negative but highly significant impact on economic growth which supports the assertion by Busari et al. (2002) that monetary policies are better suited when they are used in targeting inflation rather than in stimulating growth. In addition, Engle-Granger co-integration test was done and showed the existence of a long run relationship between monetary policy and economic growth in Nigeria. Finally, granger causality test was done on our variables and the results showed the existence of a uni-directional causality between money supply and economic growth, economic growth granger causing liquidity ratio and exchange rates while a bi-directional causality exists between interest and economic growth. We recommend that partial autonomy should be replaced with full autonomy for the central banks in Nigeria which is invariably subjected to government interference and its politics. Finally, monetary policies should be used to create a favorable investment climate by facilitating the emergency of market based interest rate and exchange rate regimes that attract both domestic and foreign investments.
\end{abstract}




\section{Subject Areas}

Economics

\section{Keywords}

Monetary Policy, Economic Growth, Engle-Granger, Instruments

\section{Background to the Study}

Monetary policy as defined by many authors is concerned with discretionary control of money supply by monetary authorities (Central Bank with Central Government) with a view of achieving stated or desired economic objectives. Most governments try to control the rate of growth of money supply because of the nexus that it has an effect on the rate of inflation.

In sum, monetary policies consist of those actions designed to influence the behavior of the monetary sector. [1] explicitly defined monetary policy as the deliberate use of monetary instruments (direct and indirect) at the disposal of monetary authorities such as central bank in order to achieve macroeconomic stability. In short, monetary policy is the tool used in achieving monetary and price stability. In most countries, the objectives of monetary policy include price stability, maintenance of balance of payments equilibrium, promotion of employment and output growth, and sustainable development.

Monetary policy in the view of [2] is a combination of measures designed to regulate the value, supply and cost of money in an economy in consonance with the expected level of economic activity. Furthermore, [3] stated that three basic monetary policy decisions can be made; the manipulation of money in circulation, the interest rate benchmark, control through a well functioning credit market and banking system.

It has been established empirically in the Nigerian economy since the 1980's that some relationship exists between the stock of money and economic growth or economic activity. The Central Bank of Nigeria (CBN) since its establishment has continued to play the traditional role of regulating the stock of money in the economy through the use of monetary policy (instruments and targets) that is usually targeted towards the achievement of full-employment equilibrium, rapid economic growth, price stability, and external balance [4]. This is very evident in the emergence and rise of an active money market where treasury bills for example have grown in volume and value becoming a key earning asset for investors and source of balancing liquidity in the market. Another popular instrument of monetary policy used by the Central Bank is the issuance of credit rationing guidelines which primarily sets the rates of interest for the components and aggregates of commercial bank loans and advances to the private sector.

Basically, the sectoral allocation of bank credit in CBN guidelines was to stimulate the productive sectors of the economy, reduce inflationary pressures, 
while the fixing of interest rates at relatively low levels was done mainly to promote investment and growth.

However, the Nigerian economy is faced with mirage of problems such as unemployment, low investment and high inflation rate and these factors militate against the growth of the economy. In truth, these problems cannot be traced to the inadequacies of monetary policies alone but also in the fluctuations in other important economic factors. This coupled with the high level of uncertainties in the monetary policy process and there is yet to be a defined set of policies and procedures that policy makers can use to deal with all situations that may arise [5]. Thus, Central Bank most times undertakes both contractionary and expansionary measures in tackling the problems of fluctuations experienced so in the economy.

\subsection{Statement of Problem}

Over the years, Nigeria has been controlling her economy through variations in her stock of money. Upon the collapse of oil prices in 1980s and the Balance of payment deficits experienced during this period various methods of stabilization (fiscal and monetary) were used and interest rates fixed [6]. [7] while evaluating the effect of Structural Adjustment Programme (SAP) opined that reducing money stock through increased interest rates reduced the Gross National Product which was in consonance with the assertions of [8] that the variations between money stock and economic activities applies to the Nigerian economy. Monetary policies can only produce desired results if a highly integrated and monetized economy with an effective networking system is available. However, the Nigerian economy as at present lacks the fundamentals to make this work [9].

The Central bank of Nigeria uses various instruments to achieve its stated objectives and these include instruments like Open Market Operation (OMO), Required Reserve Ratio (RRR), Bank Rate, Liquidity Ratio, Selective Credit Control and Moral suasion. Over the years, there have been various monetary policy regimes in Nigeria (tight and loose) with the overall aim of stemming inflationary pressures. In addition, the Nigerian economy has also witnessed times of expansion and contraction with an unsustainable growth pattern. The country suffers from the institutional and market failures that keep countries perpetually keeps its citizenry poor. In recent times, persistent exchange rate depreciations increase the relative profitability of investing in tradable, a reason why episodes of undervaluation are unfortunately strongly associated with higher economic growth. Thus, interest rate is an important determinant of economic growth in Nigeria.

Therefore, the question on whether or not monetary policy measures actually impact on the Nigerian economy still remains unsolved. The aim of this study is to evaluate the impact of the monetary policies implemented over the years on economic growth. 


\subsection{Research Questions}

In light of this, therefore, the questions to guide this research study include the following:

1) Why has the monetary policies of the Central Bank through its instruments and targets not have any significant impact on economic growth in Nigeria?

2) What are the causes of the inability of these policies in achieving their stated objectives and the possible solutions?

\subsection{Research Objectives}

The broad objective of the paper is to evaluate the impact of monetary policies on economic growth in Nigeria.

Furthermore, the specific objectives include:

1) If there is a relationship (causal) between monetary policies and economic growth in Nigeria.

2) Evaluate the impact of monetary policies on economic growth in Nigeria.

3) Proffer solutions on how monetary policies could be formulated and implemented that would lead to growth of the economy.

\subsection{Statement of Hypothesis}

In this study we shall examine the following hypotheses that:

1) $\mathrm{H}_{0}$ : There is no relationship between monetary policies and economic growth in Nigeria.

$\mathrm{H}_{1}$ : There is a relationship between monetary policies and economic growth in Nigeria. This would be evaluated using the aid of descriptive statistics and causal analysis.

2) $H_{0}$ : Monetary policies have no significant impact on economic growth in Nigeria.

$\mathrm{H}_{1}$ : Monetary policies have a significant impact on economic growth in Nigeria.

This would be empirically tested by testing the short run and long run dynamics of variables using VECM model. The organization of this paper goes thus: chapter two includes literature review, chapter three research methodologies, chapter four presentations of results and chapter five summary, conclusion and recommendations.

\section{Empirical Literature}

Empirical literatures in middle-income economies show that monetary policy shocks have little or no effects on economic parameters. [10] studied the effects of monetary shocks in ten Central and Eastern European (CEE) countries and found no evidence that suggests that changes in exchange rates and not interest rates affect output. In the same vein, Starr [11] using an Structural VAR model with orthogonalized identifications found minimal evidences of real effects of monetary policy in five Commonwealth states. However, the results that were 
inconsistent with empirical expectations from different data in different countries are what economist now refers to as "puzzles". The puzzles identified in most literature were; the liquidity puzzle, the price puzzle and the exchange rate puzzle.

The liquidity puzzle simply means than an increase in monetary aggregates is usually accompanied by an increase (rather than a decrease) in interest rates. The price puzzle is somewhat complicated as data show that a contractionary monetary policy complemented by positive innovations in the interest rate lead to an increase (rather than a decrease) in prices. Lastly, the most visible in most open economies is the exchange rate puzzle, which is a finding that an increase in interest rate is associated with depreciation (rather than appreciation) of the local currency. However, recent studies following the frameworks built by Lucas [12] [13] have devised convenient ways of eradicating these puzzles through the introduction of assumptions of rational expectations in their studies.

In the Nigerian context, data on the effect of monetary policy on economic growth shows a weak relationship and full of "puzzles". [14] using a simultaneous equation model to test the hypothesis of monetary policy effectiveness in Nigeria found that rather than promoting growth, past domestic monetary policy has been a source of stagnation and persistent inflation in the country. In addition, the impact of monetary policy on growth in Nigeria generated large volumes of empirical studies with mixed findings using cross sectional, time series and panel data. [15] using the simplified Ordinary Least Squared technique for the period 1886 to 2009 examined the effect of monetary policy on macroeconomic variables in Nigeria. In his results, monetary policy was found to have significant effect on both exchange rate and money supply but not on price stability. Furthermore, [16] reviewed the effectiveness of monetary and fiscal policy on economic activity in Nigeria using co-integration and error correction modeling techniques using time series data for the period 1970 to 1998. It was revealed that monetary rather than fiscal policy exerts a greater impact on economic activity in Nigeria while reaching a conclusion that past emphasis on fiscal measures by the government has led to greater distortion in the economy.

Hameed et al. [17] in presenting a review on how the decisions of monetary authorities influence macro variables like GDP, money supply, interest rates, exchange rates and inflation using the method of least square OLS found that tight monetary policy (in term of increase interest rate) had significantly negative impact on output, therefore asserting that increase in money supply has strong positive impact on inflation but affects output negatively. In addition to this exchange rate was found to be negatively related to output.

[18] analyzed the impact of monetary and fiscal policies on non-oil exports in Nigeria from 1974 to 2003. Using Ordinary Least Squares estimation, the study revealed that both interest rate and exchange rate, both proxies for monetary policy negatively affect non-oil exports. Similarly, budget deficits-proxy for fiscal policy also had a negative effect on non-oil exports. He therefore recom- 
mended the introduction of new strategies for monetary policy implementations to address this problem.

This leads us to the work by [19] who examined the relationship between financial innovations and monetary control and conclude that in a changing financial structure, Central Authorities cannot realize an efficient monetary policy without setting new procedures and instruments in the long-term. This is because profit- seeking institutions change and create new instruments in order to evade regulations or respond to the current conditions in the economy. The evolution of monetary policy in Nigeria in the past four decades clearly show that though monetary policy management in the country was relatively more successful during the period of financial sector reforms characterized by the use of indirect rather than direct monetary policy tools, nevertheless, the effectiveness of monetary policy has been undermined by factors such as a stronger fiscal dominance, political interference, and the legal environment in which the Central Bank operates.

In conclusion, [20] opined that monetary policy stabilizes the economy better under a flexible exchange rate system than in a fixed exchange rate system which stimulates growth at the initial period but is accompanied by severe depression thereby destabilizing sustainable growth. This basically explains the empirically backed belief that monetary policies are better suited when they are used in targeting inflation rather than in stimulating growth.

\section{Methodology}

This study would make use of secondary data to be obtained from the Central Bank of Nigeria (CBN) Statistical Bulletin. The time series data cover the period 1981-2016. Taking a leaf from [21] we intend to develop a model that is able to investigate how monetary policies affect economic growth in Nigeria. The study adopts an econometric model in determining the impact of monetary policy on economic growth in Nigeria using long and short run dynamics through different techniques such as the Augmented Dickey-Fuller (ADF), Unit Root test, Johansen Co-integration test and Vector Error Correction Mechanism (VECM).

From the above, our model is specified as thus:

Implicit form:

$$
\mathrm{GDP}=\mathrm{f}(\mathrm{MS}, \mathrm{IR}, \mathrm{ER}, \mathrm{LR})
$$

Transformed with the aid of logarithm into:

$$
\log (\mathrm{GDP})=\beta_{0}+\beta_{1} \log \mathrm{MS}_{\mathrm{it}}+\beta_{2} \log \mathrm{IR}_{\mathrm{it}}+\beta_{3} \operatorname{logER} \mathrm{E}_{\mathrm{it}}+\beta_{4} \log \mathrm{LR}_{\mathrm{it}}+\varepsilon_{\mathrm{it}}
$$

where: $\log (\mathrm{GDP})$ represents the log of Gross Domestic Product (income) at constant price.

$\log \mathrm{MS}_{\mathrm{it}}$ represents log of Money Supply.

$\log \mathrm{IR}_{\mathrm{it}}$ represents log of the Capital Rate.

$\log \mathrm{ER}_{\mathrm{it}}$ represents the log of the Exchange Rate.

$\log L R_{i t}$ represents the $\log$ of the Liquidity Ratio. 
$\varepsilon_{\text {it }}$ is the error term/disturbance term.

$\beta_{0}$ is the intercept or constant term.

$\beta_{1}, \beta_{2}, \beta_{3}, \beta_{4}$ are the estimating parameters of the model and are non negative.

\section{Presentation of Results}

\subsection{Descriptive Statistics}

Mean is the average value of the series, obtained by adding up the series and dividing by the number of observations. Median is the middle value (or average of the two middle values) of the series when the values are ordered from the smallest to the largest. The median is a robust measure of the center of the distribution that is less sensitive to outliers than the mean. Max and Min are the maximum and minimum values of the series in the current sample. Std Dev. (standard deviation) is a measure of dispersion or spread in the series. Skewness is a measure of asymmetry of the distribution of the series around its mean. Kurtosis measures the peakedness or flatness of the distribution of the series. If the kurtosis exceeds 3 , the distribution is peaked (leptokurtic) relative to the normal; if the kurtosis is less than 3 , the distribution is flat (platykurtic) relative to the normal. Jarque-Bera is a test statistic for testing whether the series is normally distributed; a small probability value leads to the rejection of the null hypothesis of a normal distribution [22].

As shown in Table 1, we notice a high maximum value for gross domestic product, money supply, exchange rate, liquidity ration and interest rate which was the period of financial sector reforms characterized by the use of indirect monetary policy instruments. Conversely the low minimum value for all our estimating parameters is explained by periods when more emphasis was laid by the government on fiscal policies rather than on monetary policies. Kurtosis which measures the peak and flatness of the distribution is flat relative to its normal distribution since their kurtosis values are less than 3 for all our estimating variables except for log of the exchange rate. Jarque-Bera is a statistical test that determines whether the series is normally distributed. The null hypothesis here is that the series is normally distributed (i.e. skewness $=0$ ) so as to be consistent

Table 1. Descriptive statistics.

\begin{tabular}{cccccc}
\hline & LogGDP & LogMS & LogER & LogLR & LogIR \\
\hline Mean & 5.91 & 5.93 & 3.61 & 2.51 & 2.51 \\
Maximum & 6.81 & 9.54 & 4.73 & 3.26 & 3.26 \\
Minimum & 5.38 & 2.67 & -0.29 & 1.79 & 1.79 \\
Std Dev & 0.43 & 2.29 & 1.40 & 0.33 & 0.34 \\
Kurtosis & 2.26 & 1.67 & 3.27 & 2.77 & 2.77 \\
Jarque-Bera & 4.58 & 2.39 & 7.57 & 0.42 & 0.42 \\
Probability & 0.10 & 0.30 & 0.02 & 0.81 & 0.81 \\
\hline
\end{tabular}

Authors computation (2018). 
with skewness test. The Jarque-Bera statistics here rejects the null hypothesis for all our market variables (GDP, MS, ER, IR, and LR) since their probability values are low. We therefore conclude that all our variables are normally distributed during the period 1981-2016.

\subsection{Unit Root Tests}

As can be seen from Table 2 and Table 3, at 5 percent level of significance, none of the variables was stationary at level since by comparison, their critical values were greater in absolute values than their augmented dicey fuller (ADF) test statistics. At first difference, GDP, INT, EXR, and LR became stationary while M2 was still not stationary. However, at second difference, all the five variables; GDP, M2, INT, EXR and LR were stationary since their Augmented Dicey Fuller Test Statistics. Thus, the series are stationary and integrated of order two, I(2).

\subsection{Estimation Results}

\section{Error Correction Model Estimation}

The next process would be the estimation of regression equation using the first level difference and the Over-parameterized error correction model (ECM).

$\log$ (GDP) c d log(GDP) $\log$ (MS) d $\log$ (MS) $\log (\mathrm{ER}) \mathrm{d} \log (\mathrm{ER}) \log (\mathrm{LR}) \mathrm{d} \log (\mathrm{LR})$ $\log (\mathrm{IR}) \mathrm{d} \log (\mathrm{IR})$.

In order to have a parsimonious model, the insignificant variables have been removed. Checking through our estimation result, we confirm that the model is a good fit from both the $\mathrm{R}^{2}(0.95)$ and adjusted $\mathrm{R}^{2}(0.93)$ and all the estimating variables except exchange rate are statistically significant (t-statistics at absolute value). Our F-statistics (49) shows a combined fit and significance for all the

Table 2. Augmented dickey-fuller unit root test at levels (trend and intercept).

\begin{tabular}{ccccc}
\hline Series & ADF test stat & $5 \%$ critical value & Order & Remarks \\
\hline $\log$ GDP & -1.488 & -3.562 & $\mathrm{I}(0)$ & Not stationary \\
$\log \mathrm{MS}$ & -2.792 & -3.557 & $\mathrm{I}(0)$ & Not stationary \\
$\log \mathrm{ER}$ & -2.036 & -3.5529 & $\mathrm{I}(0)$ & Not stationary \\
$\operatorname{logLR}$ & -2.985 & -3.5529 & $\mathrm{I}(0)$ & Not stationary \\
$\log \mathrm{IR}$ & -2.8093 & -3.5578 & $\mathrm{I}(0)$ & Not stationary \\
\hline
\end{tabular}

Authors computation (2018).

Table 3. Augmented dickey-fuller unit root test at first difference (trend and intercept).

\begin{tabular}{ccccc}
\hline Series & ADF test stat & $5 \%$ critical value & Order & Remarks \\
\hline $\log$ GDP & -4.990 & -3.568 & $\mathrm{I}(1)$ & Stationary \\
$\log \mathrm{MS}$ & -2.733 & -3.574 & $\mathrm{I}(1)$ & Not stationary \\
$\operatorname{logER}$ & -6.776 & -3.558 & $\mathrm{I}(1)$ & Stationary \\
$\log \mathrm{LR}$ & -5.951 & -3.563 & $\mathrm{I}(1)$ & Stationary \\
$\log \mathrm{IR}$ & -6.508 & -3.563 & $\mathrm{I}(1)$ & Stationary \\
\hline
\end{tabular}

Authors computation (2018). 
estimating variables while our Durbin-Watson figure of over 2 shows no sign of serial autocorrelation between the estimating variables and the residual term. From our results, we see that money supply and exchange rate all have a positive but fairly insignificant impact on Nigeria's economic growth between 1981 and 2016 while liquidity ratio and interest rate have a negative but fairly insignificant impact on growth. It clearly backs the assertion by [20] that monetary policies are better suited when they are used in targeting inflation rather than in stimulating growth.

\subsection{Co-Integration Test Results}

We intend to know if there exists a long run relationship between all our estimating variables. Since all of our variables bar the monetary supply measure are all stationary at $1^{\text {st }}$ difference we make use of the Johansen-Juleus test. The Johansen test revealed at least one co integrating equations among all our estimating variables at $5 \%$ critical value. Thus, there exist a long run relationship between monetary policy instruments (proxy by MS, ER, IR, and LR) and economic growth in Nigeria.

\subsection{Granger Causality Test}

From hypothesis one, we have to test to know the causal relationship that exists between monetary policy and economic growth. Our result with the help of granger-causality is summarized below:

1) Uni-directional causality between money supply $\log (\mathrm{MS})$ and economic growth when the coefficient of $\log (\mathrm{MS})$ is statistically significant.

2) GDP granger-cause liquidity ratio $\log (\mathrm{LR})$.

3) GDP granger-cause exchange rate $\log (\mathrm{ER})$.

4) Bi-directional causality between interest rate $\log (\mathrm{IR})$ and economic growth when the coefficient of the two variables are statistically significant.

\section{Conclusions and Recommendations}

\subsection{Conclusions}

The paper examined the impact of monetary policy on economic growth in $\mathrm{Ni}$ geria by developing a model that is able to investigate how monetary policy of the government has affected economic growth through the use of multi-variable regression analysis. We proxied the variables of monetary policy instruments to include: Money Supply (MS), Exchange Rate (ER), Interest Rate (IR), and Liquidity Ratio (LR). Economic growth was represented by Gross Domestic Product (income) at constant prices.

Unit root test was conducted and all our estimating variables were stationary at first difference except the component of interest rate which shows that our model interpretation would not be spurious and a true representation of the relationships that exists between the explained and explanatory variables. Error Correction Model was introduced in our estimation in order to have a parsimo- 
nious model.

From our result, two variables (money supply and exchange rate) had a positive but fairly insignificant impact on economic growth. Measures of interest rate and liquidity ratio on the other hand, had a negative but highly significant impact on economic growth which supports the assertion by [20] that monetary policies are better suited when they are used in targeting inflation rather than in stimulating growth. In addition, Engle-Granger co-integration test was done and showed the existence of a long run relationship between monetary policy and economic growth in Nigeria. Finally, granger causality test was done on our variables and the results showed the existence of a uni-directional causality between money supply and economic growth, economic growth granger causing liquidity ratio and exchange rates while a bi-directional causality exists between interest and economic growth.

\subsection{Recommendations}

1) Partial autonomy should be replaced with full autonomy for the central banks in the developing economies at large which is invariably subjected to government interference and its politics.

2) Monetary policies should be used to create a favorable investment climate by facilitating the emergency of market based interest rate and exchange rate regimes that attract both domestic and foreign investments.

\section{References}

[1] Dwivedi, D.N. (2005) Managerial Economics. 6th Edition, VIKAS Publishing House PVT LTD., New Delhi.

[2] Folawewo, A.O. and Osinubi, T.S. (2006) Monetary Policy and Macroeconomic Instability in Nigeria: A Rational Expectation Approach. Journal of Social Sciences, 12, 93-100.

[3] Ogunjimi, S.O. (1997) Public Finance for Polytechnics ICAN Students. Lekem Productions, Bida.

[4] Fasanya, I.O. and Onakoya, A.B.O. (2013) Does Monetary Policy Influence Economic Growth in Nigeria? Asian Economic and Financial Review, 3, 635-646.

[5] Chimezie, E.M. (2012) The Performance of Monetary Policy in the Nigerian Economy. Unpublished B.Sc. Thesis, Caritas University, Amorji-Nike Enugu, Enugu State.

[6] Ojo, M.O. (1989) Analysis of Some Prison Data. Journal of Applied Statistics, 16, 377-383. https://doi.org/10.1080/02664768900000046

[7] Ikhide, S.I. and Alawode, A.A. (1993) Financial Sector Reforms, Macroeconomic Instability and the Order of Economic Liberalization: Evidence from Nigeria. AERC Workshop Paper, Nairobi.

[8] Laidler, D. (1993) The Demand for Money; Theories, Evidence and Problems. 4th Edition, Harper Collins, New York.

[9] Familoni, K.A. (1989) Development of Macroeconomic Policy. Concept Publications, Lagos.

[10] Ganev, G., Krisztina, M., Krzysztof, R. and Prsemyslaw, W. (2002) Transmission 
Mechanism of Monetary Policy in Central and Eastern Europe. Centre for Social and Economic Research, Report No. 52. https://doi.org/10.2139/ssrn.1432336

[11] Starr, M.A. (2005) Does Money Matter in the CIS? Effects of Monetary Policy on Output and Prices. Journal of Comparative Economics, 33, 441-461. http://www.sciencedirect.com

[12] Lucas, R.J. (1972) Expectations and the Neutrality of Money. Journal of Economic Theory, 4, 103-144.

[13] Mishkin, F.S. (2002) The Role of Output Stabilization in the Conduct of Monetary Policy. Working Paper No. 9291.

[14] Balogun, E. (2007) Monetary Policy and Economic Performance of West African Monetary Zone Countries. MPRA Paper No. 3408.

[15] Amassoma, O., Ditimi, N., Nwosa, P. and Olaiya, S. (2011) An Appraisal of Monetary Policy and Its Effect on Macro Economic Stabilization in Nigeria. Journal Trends in Economics and Management Science, 2, 233-237.

[16] Ajisafe, R.A. and Folorunso, B.A. (2002) The Relative Effectiveness of Fiscal and Monetary Policy in Macroeconomic Management in Nigeria. The African Economic and Business Review, 3, 23-40.

[17] Hameed, G., Khalid, M. and Sabit, R. (2012) Linkage between Monetary Instruments and Economic Growth. Universal Journal of Management and Social Sciences, 2, 69-76.

[18] Chukuigwe, E.C. and Abili, I.D. (2008) An Econometric Analysis of the Impact of Monetary and Fiscal Policies on Non-Oil Exports in Nigeria. African Economic and Business Review, 6, 59-64.

[19] Kogar, C. (1995) Financial Innovations and Monetary Control. The Central Bank of the Republic of Turkey Discussion Paper No. 9515.

[20] Busari, D., Omoke, P. and Adesoye, B. (2002) Monetary Policy and Macroeconomic Stabilization under Alternative Exchange Rate Regime: Evidence from Nigeria.

[21] Precious and Palesa (2004) Impact of Monetary Policy on Economic Growth; A Case Study of South Africa. Mediterranean Journal of Social Sciences, 5, 76-84.

[22] Eviews (2009) Eviews 7 User Guide. Quantitative Micro Software. 


\section{Appendix}

\begin{tabular}{|c|c|c|c|c|}
\hline \multicolumn{5}{|c|}{ Dependent Variable: $\log (\mathrm{GDP})$} \\
\hline \multicolumn{5}{|l|}{ Method: Least Squares } \\
\hline \multicolumn{5}{|c|}{ Date: 04/01/18 Time: $15: 02$} \\
\hline \multicolumn{5}{|c|}{ Sample (adjusted): 19822012} \\
\hline \multicolumn{5}{|c|}{ Included observations: 31 after adjustments } \\
\hline Variable & Coefficient & Std. Error & t-Statistic & Prob. \\
\hline $\log (\mathrm{MS})$ & 0.148753 & 0.014982 & 9.928853 & 0.0000 \\
\hline $\log (\mathrm{ER})$ & 0.045527 & 0.033356 & 1.364874 & 0.1867 \\
\hline $\log (\mathrm{LR})$ & -0.339447 & 0.182799 & -1.856944 & 0.0774 \\
\hline $\log (\mathrm{IR})$ & -0.290017 & 0.112835 & -2.570270 & 0.0178 \\
\hline $\mathrm{C}$ & 6.830636 & 0.551255 & 12.39106 & 0.0000 \\
\hline $\mathrm{D}(\log (\mathrm{GDP}))$ & 0.920970 & 0.367087 & 2.508859 & 0.0204 \\
\hline $\mathrm{D}(\log (\mathrm{MS}))$ & 0.066233 & 0.243821 & 0.271648 & 0.7885 \\
\hline $\mathrm{D}(\log (\mathrm{ER}))$ & -0.054887 & 0.031060 & -1.767139 & 0.0917 \\
\hline $\mathrm{D}(\log (\mathrm{LR}))$ & 0.177415 & 0.134648 & 1.317620 & 0.2018 \\
\hline $\mathrm{D}(\log (\mathrm{IR}))$ & 0.099278 & 0.119521 & 0.830628 & 0.4155 \\
\hline R-squared & 0.954626 & \multicolumn{2}{|c|}{ Mean dependent var } & 5.917422 \\
\hline Adjusted R-squared & 0.935180 & \multicolumn{2}{|c|}{ S.D. dependent var } & 0.435016 \\
\hline S.E. of regression & 0.110754 & \multicolumn{2}{|c|}{ Akaike info criterion } & -1.307309 \\
\hline Sum squared resid & 0.257597 & \multicolumn{2}{|c|}{ Schwarz criterion } & -0.844732 \\
\hline Log likelihood & 30.26329 & \multicolumn{2}{|c|}{ Hannan-Quinn criter. } & -1.156521 \\
\hline F-statistic & 49.09087 & \multicolumn{2}{|c|}{ Durbin-Watson stat } & 2.927862 \\
\hline Prob (F-statistic) & 0.000000 & & & \\
\hline
\end{tabular}

